\title{
JEJAK TUANTA SALAMAKA DAN TRADISI ZIARAH KUBUR SEBAGAI BENTUK BUDAYA SPIRITUAL
}

\section{THE FOOTSTEPS OF TUANTA SALAMAKA AND THE TRADITION OF THE PILGRIMAGE AS A FORM OF SPIRITUAL CULTURE}

\author{
Nur Alam Saleh \\ Balai Pelestarian Nilai Budaya Sulawesi Selatan \\ Jalan Sultan Alauddin/Tala Salapang KM.7 Makassar \\ email: salehnuralam@gmail.com \\ DOI: $10.36424 /$ jpsb.v5i2.142 \\ Naskah Diterima 25 September :2019 Naskah Direvisi:22 Oktober 2019 \\ Naskah Disetujui: 22 Oktober 2019
}

\begin{abstract}
Abstrak
Penelitian ini membahas tentang keberadaan Makam Syekh Yusuf atau dikenal juga dengan Tuanta Salamaka. Penelitian ini di lakukan di Kelurahan Katangka Kecamatan Sombaopu Kabupaten Gowa. Jenis penelitian kualitatif dengan tipe deskriptif. Data diperoleh dengan melakukan observasi/pengamatan, wawancara dan dokumentasi. Adapun teknik analisis data yaitu reduksi data, penyajian data dan penarikan kesimpulan. Berdasarkan hasil penelitian dapat menyimpulkan 1 . Sosok Syekh Yusuf selain dikenal sebagai seorang ulama, sufi dan cedikiawan yang arif, juga adalah pejuang (pahlawan). 2. Motivasi spiritual para peziarah terbagi dalam tiga kategori, yaitu motivasi aqidah, ibadah dan muamalah. 3. Ditinjau dari sosial ekonomi, memberikan dampak positif bagi masyarakat sekitar dengan meningkatnya kesejahteraan mereka.
\end{abstract}

Kata Kunci : Syekh Yusuf, makam dan budaya spiritual

\begin{abstract}
This research discussing about the existence of the Grave of Syeikh Yusuf or also known as Tuanta Salamaka. This research conducted in Katangka District, Sombaopu Sub-district, Gowa Regency. This is qualitative-descriptive research. The data derived from observation, interview, and documentation. The data analysis techniques are data reduction, data presentation, and conclusion drawing. Based on the research results, it can be concluded that, 1. Beside known as Ulama, Sufi, and a scholar, Syeikh Yusuf also known as a warrior (hero). 2. The spiritual motivation of the pilgrims divided into 3 categories: aqidah, worship, and muamalah. 3. In terms of social economy, benefits the communities around with the rising prosperity.
\end{abstract}

Keyword: Syeikh Yusuf, Grieve, and Spiritual culture 


\section{PENDAHULUAN}

Hasil pemikiran cipta dan karsa manusia merupakan kebudayaan yang berkembang pada masyarakat.Pikiran dan perbuatan yang dilakukan manusia secara terus menerus pada akhirnya menjadi sebuah tradisi.Sejalan dengan adanya penyebaran agama, tradisi yang ada di masyarakat dipengaruhi oleh ajaran agama yang berkembang. (Clifford Geertz, 1983:89) Dengan kondisi seperti itu, maka terjadi banyak kebudayaan yang berkembang dalam kehidupan masyarakat tetap terpelihara, salah satunya adalah tradisi yang berbentuk ziarah makam.

Di Indonesia yang masyarakatnya mayoritas beragama Islam sangat menghormati kepada orang-orang suci, termasuk "makam" pun dianggap sebagai "makam" keramat, bahkan merupakan bagian dari ritus keagamaan. Di samping itu bentuk bangunannya nampak memberi kesan kekeramatan yang semakin tinggi dan penuh misteri. Apalagi bila dikaitkan dengan kepercayaan asli sebagian masyarakat yang masih memuja roh para leluhur, sehingga makam dari tokoh atau orang-orang yang dianggap suci itu selalu dikeramatkan. Boleh juga suatu areal "makam" akan menjadi keramat setelah seorang Islam yang kharismatik dikuburkan ditempat itu.

Tradisi ziarah dikalangan umat Islam Indonesia, khususnya daerah Sulawesi Selatan Kabupaten Gowa masih sangat kuat. Kegiatan ini menjadi agenda tersendiri dalam memenuhi kegiatan keagamaan. Munculnya motif di luar tujuan ziarah, terlebih ketika sudah diiringi dengan praktik-praktik yang meniru tradisi pra-Islam, tak pelak sebagian orang menilai ini merupakan kegiatan syirik. Terkadang para peziarah pun tidak memahami mana sebenarnya yang merupakan tuntunan Islam dan mana yang merupakan tradisi nenek moyang atau warisan dari tradisi kuno.

Makna ziarah tidak hanya mengunjungi pemakaman semata tetapi terdapat sebuah niat untuk mendoakan dan mengambil pelajaran dari kegiatan ziarah tersebut. Ziarah kubur biasa dilakukan dengan mengunjungi makam-makam keluarga, kerabat, tokoh masyarakat, ulama, wali dan nabi yang telah berjasa. Dalam pandangan masyarakat yang sering melakukan ziarah kubur, diantaranya bahwa roh orang suci itu memiliki daya melindungi alam. Orang suci yang 
meninggal, arwahnya tetap memiliki daya sakti, yaitu dapat memberikan pertolongan kepadaorang yang masih hidup, sehingga anak cucu yang masih hidup senantiasa berusaha untuk tetap berhubungan dan memujanya.

Ziarah ke makam Syekh Yusuf atau yang lebih dikenal dengan tuanta salamaka merupakan salah satu aktivitas yang dilakukan sejak lama oleh masyarakat pada umumnya dan memang sudah menjadi langganan ziarah sebagai wisata spiritual umat Islam. Makam Syekh Yusuf yang terletak di Kelurahan Katangka Kecamatan Somba Opu Kabupaten Gowa, sangat dihormati, dikagumi dan dipuja-puja bukan saja oleh masyarakat setempat bahkan mereka yang berasal dari luar daerah itu. Makam yang dibangun diatas areal tanah seluas kurang lebih 3000 meter persegi dan biasa pula disebut dengn nama kobbanga (kubah red) itu, dalam setiap harinya ramai dikunjungi peziarah dari berbagai lapisan sosial masyarakat yang tentunya sesuai dengan relefansi serta kepentingan yang berbeda.

Sosok Syekh dalam menegakkan kebenaran tidak saja dimuka bumi ini, melainkan juga berjuang menegakkan hak-hak kemanusiaan di tanah dimana pernah dijejakinya, mulai dari Timur Tengah, Srilangkah sampai ke Afrika Selatan. Kendatipun telah lebih kurang dari 300 tahun meninggalkan para pengikutnya, namun atas kecendikiawan dan kepahlawanannya sehingga menjadikannya tersohor sampai sekarang tetap dikenang dan dihormati.

Dalam perkembangannya tujuan para peziarah pun bermacam-macam. Jika pada awalnya ziarah ini bertujuan mendapatkan berkah dari Tuanta Salamaka, maka pada perkembangannya mengalami berbagai macam motivasidan tujuan. Selain itu, tidak sedikit pula yang hadir dalam rangka menunaikan hajat pribadi. Umumnya kegiatan ziarah ini disamping sebagai pengingat datangnya kematian, mengenang perjuangan dari Tuanta Salamaka sebagai tokoh sejarah juga tidak sedikit dari peziarah yang berziarah mencari berkah agar dilancarkan rezekinya, dipermudah jodohnya atau mungkin agar menduduki jabatan tertentu dan berhasil dalam pemilihan pilkada, pileg dan sebagainya.

Di era yang sudah modern seperti sekarang ini peziarah yang melakukan ziarah ke makam Tuanta Salamaka biasanya melakukan kegiatan-kegiatan 
tertentu,seperti membersihkan makam, menaburkan bunga, tawassul, berdoa, berdzikir, tahlil, shalawat dan lain sebagainya. Kepercayaan para peziarah memang sangatlah mengkeramatkan makam Tuanta Salama ka ini. Meskipun demikian, kepercayaan tersebut tidaklah tunggal karena sangat tergantung pada pola pikir, pemahaman keagamaan dan tradisi yang melingkupinya. Kepercayaan yang berbasis pada pola tradisional Islam, kepercayaan mistis yang berbasis pada tradisi, dan kepercayaan yang berdasarkan pada pemikiran rasional belaka. Berbagai ragam kepercayaan ini menunjukkan bahwa kita tidak bisa membuat klaim-klaim sepihak kepada motivasi para peziarah yang datang ke makam Tuanta Salamaka.

Sehubungan dengan keberadaan Makam Syekh Yusuf di Lakiung Kelurahan Katangka Kabupaten Gowa yang sampai saat ini masih dapat kita jumpai, maka dalam kaitannya dengan tulisan ini fokus perhatian diarahkan pada beberapa masalah pokok sebagai berikut: Bagaimana latar belakang kehidupan dan perjuangan Syekh Yusuf yang di sampai saat ini dikenal sebagai Sosok Syekh dalam menegakkan kebenaran tidak saja di negeri ini, melainkan juga berjuang menegakkan hak-hak kemanusiaan di tanah dimana pernah dijejakinya, mulai dari Timur Tengah, Srilangkah sampai ke Afrika Selatan. Demikian pula dalam menuntut ilmu dan penyebaran ajaran di daerah ini sampai akhir hayatnya.

Masalah lainnya yang cukup penting untuk diungkapkan dalam tulisan ini, yakni sejauh manakah pemanfaatan ziarah kubur di makam Syekh Yusuf "Tuanta Salamaka". Apakah ada kemungkinan asset tersebut dapat dikelolah sehingga dapat dijadikan salah satu objek wisata religius (ziarah).Bagaimana tanggapandari kalangan masyarakat tentang keberadaan Makam Syekh Yusuf manakala dijadikan sebagai objek wisata budaya, apa saja pengaruhnya bagi masyarakat sekitar makam serta apa saja motivasi spiritual masyarakat peziarah makan Tuanta salama.

\section{METODE PENELITIAN}

Penelitian ini dilakukan dengan mengambil lokasi di wilayah admi nistratif Sungguminasa, Kecamatan Somba opu, Kabupaten Gowa. Kecamatan ini 
merupakan Ibu Kota kecamatan yang mempunyai tingkat pertumbuhan penduduk yang tinggi di Kabupaten Gowa dimana disilah lokasi makan Syekh Yusuf atau dikenal juga dengan Tuanta Salamaka .Penelitian ini adalah penelitian kualitatif, metode penelitian kualitatif adalah metode penelitian yang digunakan untuk meneliti pada objek yang alamiah, (sebagai lawannya adalah eksperimen) dimana peneliti adalah sebagai instrumen kunci (Koentjaraningrat, 1965:77-78). Namun jika dilihat dari tempat memperoleh data maka penelitian ini temasuk penelitian lapangan (field research).

Selain itu, peneliti juga menggunakan kajian pustaka (library research) yaitu pengumpulan data atau penyelidikan melalui perpustakaan dengan membaca buku-buku dan karya ilmiah yang relevan dengan penelitian. Pengumpulan data sangatlah penting dalam suatu penelitian, karena tanpa data maka hasil penelitian akan diragukan keotentikannya. Dalam hal ini ada dua jenis data yang akan digunakan, yaitu data primer dan data sekunder. Teknik pengumpulan data dengan dokumentasi ialah pengambilan data yang diperoleh melalui dokumen-dokumen (Atang Abd Hakim, 2000:32). Data yang dikumpulkan dengan teknik dokumentasi ini cenderung merupakan data sekunderarena data yang diperoleh berasal dari buku-buku maupun gambar yang kemudian diteliti dan dikaitkan dengan kenyataan yang dihadapi di lokasi penelitian.Metode penelitian pengumpulan data dengan melakukan Observasi atau pengamatan, wawancara dan dokumetasi.

\section{PEMBAHASAN}

\section{A. Sejarah Tuanta Salamaka}

Sosok Syekh Yusuf selain dikenal sebagai seorang ulama, sufi, dan cendikiawan yang arif juga adalah pejuang (pahlawan). Sebagai seorang pahlawan, ia juga merupakan sosok pemimpin yang berani dan cerdas serta ahli strategis dalam perang.Dalam catatan sejarah menyebutkan kompeni Belanda memilih untuk merebut Makassar dan menyusul Banten. Makassar menguasai perairan maluku dan Indonesia bagian timur. Sementara banten menguasai perairan bagian barat. Hal tersebut dapat diketahui dan masuk strategi pertahanan 
Sultan Ageng Tirtayasa atas nasihat Syekh Yusuf. Dalam sejarah menyebutkan kompeni Belanda memilih untuk merebut Makassar dan menyusun Banten. Makassar menguasai perairan Maluku dan dan Indonesia Bagian Timur. Sementara Banten mengusai perairan Indonesia Bagian Barat. Hal tersebut dapat diketahui dan masuk strategi pertahanan Sultan Akeng Tirtayasa atas nasihat Syekh Yusuf.

Semua gerakan kompeni ini diamati oleh Banten dan berusaha sekuat tenaga untuk mempersiakan diri menghadapi perang sesudah Makassar. Sultan Ageng Tirtaya bersama Syekh Yusuf yang juga sebagai menantunya pada saat itu, semakin terlibat dalam situasi politik, ekonomi, dan sosial, menggalang persatuan dan kesatuan rakyat. Syekh Yusuf semakin populer dan mempunyai kharisma, serta makin disegani oleh kompeni.

Mengenal asal usul dan kisah perjalanan hidup Syekh Yusuf, begitu banyak di warnai dan diselimuti dengan mitos serta legenda. Hal ini sangat dimungkinkan karena sosok Syekh Yusuf selain dipandang sebagai seorang ulama besar Islam, juga adalah pejuang (pahlawan). Disamping itu dia juga dianggap sebagai sufi atau wali, yang memiliki ketinggian ilmu melebihi dari manusia biasa.

Cerita tentang mitos disekitar tokoh Syekh Yusuf nampak sebagian besar mempuyai ciri yang sama mengenai mitos seorang tokoh di pulau jawa. Juga tak dapat disangkal bahwa karena berbagai mitos inilah akhirnya yang merupakan salah satu faktor unsur pemujaan terhadap Syekh Yusuf di Sulawesi Selatan (1995/1996:53). Demikian sehingga dari kedua orang tuanya, yakni bapak dan ibunya sampai kepada prooses kelahirannya dan perjalanan hidupnya sangat diwarnai dengan mitos.

Dalam salah satu versi lontarak dikisahkan kalau ayah Syekh Yusuf adalah Nabi Khaidir. Ketika itu dia menyamar sebagai orangtua yang memiliki keistimewaan yang sangat luar biasa. Demikian pula bila berjalan kaki maka kakinya tidak menyentuh tanah. Demikian halnya dengan istrinya yang bernama Aminah anak dari Gallarang Moncongloe yang mempunyai paras sangat cantik itu diberikan kepada Sultan Alaudin untuk dijadikan istrinya. 
Muhammad Yusuf atau Syekh Yusuf semenjak kecil sampai dengan masa remajanya, sudah memperlihatkan bahwa ia seorang anak yang memiliki kecerdasan yang sangat luar biasa, apabila dibandingkan anak-anak lain seusiannya. Dalam usianya yang sangat relatif muda itu, Syekh Yusuf sudah menamatkan 30 jus dalam waktu singkat.

Dikisahkan pula sebelum Syekh Yusuf mengadakan perantauan kepulau jawa dan meneruskan ke tanah suci Mekkah untuk menuntut ilmu Agama, ia terlebih dahulu belajar pada dua orang guru masing-masing Datok ri Panggentungang dan I Lomo ri Antang. Baik Datok ri Panggentungang maupun I Lomo ri Antang adalah guru yang pertama menanamkan benih-benih tasawauf serta banyak memberikan latihan fisik dan mental kepada Syekh Yusuf. Dari kedua gurunya itu pulalah yang membawa Syekh Yusuf mengembara ke hutanhutan belantara sampai ke Gunung Bawakaraeng dan bertemu seorang bertemu dengan seorang Waliyullah.

Dikisahkan pula dalam setiap perjalanan yang dilakukan oleh Syekh Yusuf itu selalu membawa serta tiga buah keris. Keris pertama diberi nama I Cakkua, kedua bernama I Dandang Kua, dan keris ketiga ialah Pagarre. I Cakku dibuat di Campagaya Gowa dan merupakan simbol bagi orang Gowa. Karena itulah sehingga muncul semboyan yang mengatakan I Cakkua-lah engkau lihat, I Danang Kua jadi contoh, dan Pangerra tidak memberi tempat didunia. Mana kala Syekh Yusuf alias Tuanta Salamaka sedang berjalan ditengah hutan belantara, maka ia mencabut kerisnya yang bernama I Cakkua. Seluruh binatang buas yang melihatnya itu lari dari menjauh sejauh mata memandang.

Dalam ceritera lainnya yang telah beredar ditengah-tengah masyarakat luas, terutama penganut aliran tarekat tajulkhawatiah dan anak cucunya itu, bahwa keberadaan arwah Syekh Yusuf di Sulawesi Selatan lebih dikenal dengan namaTuanta Salamaka, dalam setiap harinya berada disuatutempat tertentu. Misalnya pada hari Senin ia berda di pulau Jawa, hari Selasa di Rawapening, ambrawa, hari Rabu di NeheriNegro-Afrika Selatan, hari Kamis berada di Lakiung (Sulawesi Selatan), hari Jum'at berada di tanah Sui Mekkah, hari Sabtu berada di negeri Cina, dan hari Ahad Syekh Yusuf bersama wali - wali. 
Demikianlah kisah dan cerita tentang Syekh Yusuf yang telah melegenda ditengah tengah masyrakat pendukungnya, sehingga beberapa mitos yang ditimbulkannya, merupakan faktor penunjang terjadinya pemujaan teradap Syekh Yusuf "Tuanta Salamaka".

\section{B. Motivasi Spiritual Masyarakat Peziah Makam Tuanta Salamaka}

Dalam kenyataan hidup masyarakat religius, maka kegiatan seperti dalam bentuk-bentuk ziarah ke makam orang-orang tertentu terutama ke makam orang orang suci, bukanlah merupakan sesuatu yang baru bagi masyarakat Sulawesi Selatan pada umumnya dan Suku Makassar pada khususnya. Sifat keuniversilan ziarah makam tidak hanya tergantung kepada fakta-fakta empiris, melainkan yang lebih penting lagi tergantung kepada tata cara menempatkannya, sebagai salah satu self controle, baik dalam kehidupan pribadi maupun masyarakat.

Setiap individu dalam melakukan sesuatu biasanya muncul karena adanya suatu dorongan yang menimbulkan seseorang mau dan bersedia melakukan sesuatu hal. Demikian pula para peziarah yang datang ke makam Tuanta Salamaka tidak akan pernah terlepas dari adanya dorongan atau motivasi dalam melakukan ziarah kubur. Motivasi adalah sesuatu yang tak bisa ditinggalkan dalam setiap kegiatan dan aktivitasnya. Seseorang akan lebih bersemangat dalam mengerjakan sesuatu apabila termotivasi oleh sesuatu yang ada di dalam maupun diluar dirinya. (Wahosumidjo, 1992:177).

Begitu pula ketika ketika seseorang atau sekelompok orang yang pergi berziarah sudah pasti memiliki motif yang berbeda antara satu dengan lainnya. Ketika ada suatu dorongan dan adanya kekuatan yang menggerakkan dan mengarahkan untuk bertindak sebagai pemuncul tingkah laku. Dorongan juga menjadikan individu akan terus melakukan suatu tindakan sampai tujuan itu tercapai karena pada hakikatnya semua tingkah laku dan perilaku manusia mempunyai motif.

Kebanyakan peziarah yakin bahwa dengan mendatangi makam Tuanta Salamaka mereka akan mendapatkan keberuntungan sesuai dengan yang dihajatkan.Peziarah yang mengunjungi makam pada umumnya telah dilandasi 
dengan niat dan tujuan yang didorong oleh kemauan batin yang sangat mantap. Masing-masing dari setiap peziarah belum tentu memiliki motivasi yang sama antara satu dengan yang lainnya. Motivasi spiritual seorang muslim terbagi menjadi tiga: motivasi aqidah, motivasi ibadah dan motivasi muamalat. Pertama, Motivasi aqidah adalah keyakinan hidup, yaitu pengikraran yang bertolak dari hati. Jadi, motivasi aqidah dapat ditafsirkan sebagai motivasi dari dalam yang muncul akibat kekuatan aqidah tersebut. Motivasi aqidah tersebut sebagai sikap intrinsik. Dimensi aqidah ini menunjuk pada seberapa besar tingkat keyakinan muslim terhadap ajaran-ajaran yang bersifat fundamental dan dogmatik.Isi dimensi keimanan mencakup iman kepada Allah, para Malaikat, Rasul-Rasul, kitab Allah, surga dan neraka, serta qadha dan qadar.Ibadah merupakan tata aturan Ilahi yang mengatur hubungan ritual langsung antara hamba Allah dengan Tuhannya yang tata caranya ditentukan secara rinci dalam Al Qur'an dan Sunnah Rasul. (Hafi Anshari, 1993 : 6)

Ziarah kuburan atau makam seseorang itu, merupakan manifestasi dari perasaan dan kebutuhan relegius setiap manusia yang muncul dari rasa keagamaan dalam dirinya percaya kepada suatu kekuatan yang dianggap lebih tinggi daripadanya. Dorongan emosi kegamaan tersebut muncul dari rasa ketakutan, kegelisahaan, ketidaktenangan didalam hatinya, pada sesuatu yang bersifat supernatural seperti takut mendapat gangguan dari roh-roh halus, takut tidak diberi keselamatan oleh tuhan dan lain sebagainya.

Dengan adanya rasa takut, gelisah dan tidak tenang inilah menyebabkan sebagian masyarakat melakukan sesuatu kegiatan ritual keagamaan, yakni salah satu diantaranya adalah ziarah kubur atau makam. Dalam kondisi seperti itu maka dapat dikatakan bahwa ziarah kubur atau makam berfungsi srpitual dalam kehidupan nasyarakat, yakni berhubungan dengan penghormatan atau pemujaan terhadap tuhan maupun kepada leluhur, yang dianggap dapat memberikan rasa aman, tenang tentram, tidak takut dan tidak gelisah serta selamat.Demikian pula halnya dengan keberadaan makam Syekh Yusuf di Lakiung, dimana sebagian besar masyarakat peziarah yang datang berkunjung itu masih memandang sebagai sesuatu yang dikeramatkan. Mereka itu juga menganggap makam tersebut dapat di 
jadikan wasilah (perantara), yang dapat digunakan untuk menyampaikan doa-doa kepada Tuhan. Sosok Syekh Yusuf baik semasa hidupnya maupun setelah meninggal dunia, dinilai sebagai orang yang lebih dekat kepada yang lebih dekat kepada Allah Swt. Seperti halnya terhadap Nabi-Nabi, para wali, ulama dan orang-orang saleh dapat dijadikan sebagai wasilah.

Sementara itu ada juga sebagian masyarakat peziarah memadangnya untuk memenuhi hadits Nabi, dengan maksud untuk mendoakan agar dapat diampuni dan amalnya diterima oleh Allah SWT. Disamping itu Makam Syekh Yusuf juga dipandang sebagai tempat untuk menghormati tokoh Islam yang kharismatik dan merupakan sosok seorang pejuang (pahlawan) sehingga Makam Syekh Yusuf sangat dihormati, dikagumi serta di puja-puja sesuai dengan relevansi dan kepentingan masing-masing para peziarah.

\section{Pengaruh Ziarah Makan Tuanta Salamaka terhadap kehidupan Sosial Ekonomi Para Peziarah dan Masyarakat Sekitar Makam}

Masyarakat yang berdiam disekitar Makam Syekh Yusuf sampai saat ini masih menganggap dirinya adalah penduduk asli Katangka Kabupaten Gowa. Hal tersebut berdasarkan dengan hasil pengamatan dan wawancara terhadap beberapa informan. Menurut Nurdin salah seorang warga yang juga pengurus LPM kelurahan setempat itu, megatakan kepada penulis bahwa disamping penduduk asli Katangka yang mendiami disekitaran makam, juga sudah terdapat beberapa penduduk pendatang dari luar. Mereka itu pada umumnya bertempat tinggal dalam lorong atau jalan Syekh Yusuf I sampai dengan IV. Sementara penduduk asli sebagian besar masih bertempat tinggal di bilangan Jalan Syekh Yusuf (jalan besar) dan berhadapan langsung dengan Kompleks Makam Syekh Yusuf, yang hanya diantarai oleh jalan.

Dg Nigga yang telah berpuluh tahun bertetangga dengan Kompleks Makam Syekh Yusuf, bahwa ada sekelompok masyarakat yang menilai kalau semua orang yang datang berziarah ke kobbang semata-mata hanya untuk menyembah makam atau kuburan Syekh Yusuf. Pendapat seperti itu, menurut dia sangat keliru dan perlu diluruskan. Kehadiran para peziarah tersebut, adalah untuk 
turut mendo'akan diri dan para keluarganya sebagaiamana yang pernah dialami oleh Syekh Yusuf Tuanta Salamaka. Tuanta Salamaka sendiri berarti Tuan (Syekh Yusuf) kita yang telah selamat. Dengan demikian para peziarah tersebut mengaharapkan diri maupun keluarganya mendapatkan keselamatan seperti yang dialamai oleh Syekh Yusuf.

Meskipun demikian, kata Syamsu yang sehari-harinya berjualan bunga dan minyak wangi serta air penyiram dalam botol itu, menilai tergantung dari niat para peziarah itu sendiri. Adalah hak masing-masing pribadi. Kendatipun diakuinya kalau dari sekian banyak peziarah yang datang berkunjung ke makam Syekh Yusuf, mungkin ada diantara mereka itu yang masih berpikiran atau beranggapan bahwa keberadaan Makam Syekh Yusuf dikeramatkan. Ditambahkan pula bahwa yang datang berziarah itu, tidak semuanya dari kalangan masyarakat beragama Islam, melainkan ada juga dari agama non islam demikian pula dengan latar belakang suku bangsanya.

Terlepas dari penafsiran yang telah dilontarkan oleh sejumlah pemuka masyarakat tentang pandangannya terhadap makam Syekh Yusuf, maka H. Saleh Nigga juga melihat adanya dampak yang ditimbulkan baik positif maupun negatif. Adapun dampak positifnya dengan keberadaan Makam Syekh Yusuf tersebut, menurutnya dapat dijadikan sebagai sumber penghasilan atau mata pencaharian, setidaknya merupakan suatu tambahan penghasilan bagi masyarakat setempat, dengan memanfaatkan aktifitas kegiatan dari para peziarah yang datang berkunjung ke Makam Syekh Yusuf. Disamping itu bagi pemerintah daerah setempat dapat pula menjadikan sebagai salah satu sumber pemasukan pendapatan asli daerah, yang saat ini telah dikelolah oleh Dinas Pariwisata Kabupaten Gowa, dengan memungut biaya masuk bagi setiap peziarah. Bahkan dimasa mendatang Kompleks Makam Syekh Yusuf dan sekitarnya dapat dijadikan sebagai kawasan wisata religius, apalgi tidak jauh dari makam tersebut terdapat sejumlah bangunan, seperti Masjid Tua Katangka, yang merupakan salah satu mesjid tertua di Sulawesi Sealatan, yang didirikan pada Tahun 1603.

Dalam upaya menjadikan Kompleks Makam Syekh Yusuf sebagai kawasan wisata ziarah (religius) dimasa depan, yang kemungkinan akan dikelolah 
oleh pemerintah kabupaten dalam hal ini Dinas Pariwisaata Kabupaten Gowa, maka menurut Sirajuddin masih banyak hal yang perlu dibenahi oleh pihak pengelolah. Sebagai contoh kecil yang harus menjadi perhatian utama, adalah masalah keamanan dan kenyamanan peziarah. Sebuah pandangan yang samapai sekarang ini masih mewarnai ziarah di Makam Tuanta Salamaka itu, adalah adanya kelompok paraggak doek (peminta-minta) yang tidak sedikit jumlahnya. Hal tersebut juga memerlukan suatu penaganan yang serius untuk dicermati, karena sangat mengganggu para peziarah yang datang ke Makam Syekh Yusuf.

Sisi negatif lainnya lagi yang terlihat dengan keberadaan Makam Syekh Yusuf di Lakiung ini, adalah terdapatnya sejumlah anak-anak yang tidak mau bersekolah lagi, karena telah tergiur untuk memperoleh uang dengan sangat mudah dari para peziarah. Anak-anak tersebut sejak pagi hari telah berada di Kompleks Makam, setelah sore hari barulah mereka beranjak pulang ke rumahnya masing-masing. Sehingga tidak mempunyai lagi waktu untuk bersekolah. Ini sangat merugikan masa depan anak itu sendiri, kunci H. Saleh. Mengakhiri wawancara dengan penulis.

Kehadiran para peziarah yang datang berkunjung ke Makam Syekh Yusuf di Lakiung telah berlangsung sejak lama. Peziarah tersebut berdatangan dari segala penjuru Sulawesi Selatan. Walaupun sebagian besar mereka itu, adalah orang-orang bugis-Makassar yang datang berziarah, namun sedikit banyaknya mempunyai dampak terhadap kehidupan masyarakat yang berdiam disekitar Kompleks Syekh Yusuf. Pengaruh yang ditimbulkan dengan ziarah makam itu, dapat berdampak positif atau sebaliknya berdampak negatif. Kalau diamati kehadiran para peziarah yang datang itu sebagian besar masih didominasi dengan orang-orang Bugis Makassar, sehingga dampak atau pengaruh dengan kehadiran mereka itu terhadap penduduk sekitar makam tidak begitu berdampak yang dapat merugikan. Apalagi baik peziarah maupun masyarakat setempat mempunyai latar belakang kebudayaan yang sama.

Ziarah makam Syekh Yusuf ini sebenarnya sangat berdampak positif dalam kehidupan masyarakat, terutama yang berada disekitar makam. Hal ini dapat kita perhatikan dengan banyaknya pihak-pihak yang memanfaatkan ziarah 
kubur tersebut untuk mendapatkan penghasilan, mulai dari anak-anak sampai kepada orang tua, dengan berjualan dan sebagainya. Dampak positif lainnya dengan adanya ziarah makam ini, terciptanya suatu kontak komunikasi antara masyarakat setempat dengan para peziarah yang datang dari berbagai daerah di Sulawesi Selatan ini. Sehingga dengan sendirinya dapat menjalin suatu persahabatan yang lebih erat. Sebagaimana dikemukakan oleh seorang informan yang sehari-harinya berjualan kembang atau bunga disekitar lokasi makam, mengaku banyak mempunyai kenalan dan sahabat dari para peziarah makam yang kebanyakan berasal dari daerah. Boleh dikata mereka itu telah berlangganan bunga, setiap datang berziarah. Sebelum masuk ke kobbanga peziarah tersebut duduk-duduk sebentar sambil ngobrol. Disitulah kami saling berkenalan sampai sekarang. Demikian pula dengan para peziarah lainnya, ujar Sila yang hanya sempat mengenyam pendidikan SMP.

Walaupun ziarah makam di Makam Syekh Yusuf Tuanta Salamaka mempunyai dampak positif sebagaimana telah dikemukakan di atas, namun terdapat pula sisi-sisi negatifnya yang cukup memprihatinkan bagi dunia pendidikan. Hal tersebut terlihat dalam keterlibatan anak-anak usia sekolah dasar maupun tingkat SMP, yang sering mangkal di koridor Makam Syekh Yusuf. Mereka itu biasanya dijuluki sebagai paraggak doek. Kegiatan paraggak doek yang tidak saja dilakonkan oleh anak-anak usia sekolah seperti yang disebutkan diatas, akan tetapi terdapat pula sejumlah anak-anak remaja maupun dewasa, bahkan ada juga orang tua. Paraggak doek ini menunggu pemberian berupa uang dari peziarah yang telah melepaskan nazar maupun yang baru mulai berhajat. Para peziarah itu biasanya telah menyiapkan uang recehan atau kertas, untuk diberikan kepada paraggak doek dengan jalan menghamburkan, sehingga anak-anak paraggak doek saling berebutan antara satu dengan yang lainnya. Namun ada juga peziarah yang memberikan secara langsung ke tangan anak-anak paraggak doek.

Masalahnya sekarang anak-anak tersebut, sudah tidak mau lagi masuk sekolah atau pergi kesekolahnya, karena telah tergiur untuk mendapatkan uang dengan mudah. Anak-anak itu tidak terlalu sulit memperoleh uang dengan tanpa bekerja keras. Sementara itu sekolah atau pendidikannya sudah tidak terabaikan 
lagi.Demikian pula apabila ditinjau dari perilaku agama (Islam), maka oleh sekelompok anggota masyarat menilai ziarah kubur di Makam Syekh Yusuf yang dilakukan sebagian masyarakat Islam yang sesungguhnya.

Menurut Rifai, mereka yang datang berziarah di Kobbang itu menganggap Makam Syekh Yusuf dijadikan sebagai washila (perantara) bagi orang-orang yang masih hidup, untuk meminta sesuai kepada Tuhan. Karena meminta-minta pada kuburan maka hukumnya musyrik yang dikutuk oleh Allah SWT, ujar Rifai sembari menunjukkan Hadist Riwayat (HR) Muslim yang menyebutkan; "Jika seseorang telah meninggal dunia (mati) maka putuslah amalnya kecuali ada tiga hal; Pertama sedekah jariah, kedua ilmu yang bermanfaat, dan ketiga anak saleh yang selalu mendoakan kedua orang tuanya.

Keberadaan kompleks Makam Syekh Yusuf di Lakiung Kelurahan Katangka Kabupaten Gowa, yang setiap harinya tidak pernah sepi dari kunjungan peziarah yang datang silih berganti. Kobbang dan kehadiran berbilang peziarah merupakan suatu berkah tersendiri, bagi sejumlah warga masyarakat yang berdiam disekitar makam Tuanta Salamaka.

Sehubungan dengan hal tersebut di atas, sehingga pada masyarakat Lakiung dikenal sebagai ungkapan dalam bahasa Makassarnya yang mengatakan tau mate antallasi tau tallasaka, artinya orang mati dapat menghidupi orang yang hidup. Maksud dari ungkapan tersebut adalah bahwa Syekh Yusuf atau lebih dikenal Tuanta Salamaka sekalipun telah lama wafat, namun masih dapat memberikan nafkah bagi orang-orang yang masih hidup.

Untuk membuktikan ungkapan Makassar tersebut, maka berikut ini beberapa informan menuturkan pengalamannya kepada penulis, sebagai mana yang di kemukakan oleh Dg. Sikki berumur 62 tahun. Bahwa sebelum dirinya menjadi salah seorang guru maca di Kobbanga pada tahun 1975, dia pernah tercatat sebagai seorang pegawai Sipil ABRI di Ujungpandang (sekarang Makassar). Setelah keluar dari instansi ABRI itu dan bergabung sebagai guru maca sampai sekarang. Menurutnya walaupun penghasilannya sebagai guru maca di Kobbanga terbilang kecil, namun dapat juga menghidupi satu orang isteri dan lima orang anak-anaknya. Dari lima orang anaknya itu tiga diantaranya sudah 
berkeluarga dan dua anaknya lagi masih kuliah. Dalam setiap harinya Sikki memperoleh passidakka (sedekah) sekitar puluhan bahkan ratusan ribu rupiah.

Dampak sosial ekonomi dari ziarah makam Tuanta Salamaka, yang paling sangat merasakannya pengaruhnya dalam masyarakat sekitar kompleks makam, dengan memanfaatkan halaman ataupun pekarangan rumahnya barang-barang atau bahanbahan yang berkaitan dengan ziarah kubur. Perlengkapan untuk ziarah kubur itu berupa kembang atau bunga yang sudah satu paket dengan tai bani (lilin merah) dan minnyak bauk (minyak harum. Disamping ada juga penduduk yang memanfaatkan rumahnya dengan menjual hewan kurban, seperi kambing dan ayam. Binatang kambing maupun ayam biasanya dibutuhkan oleh peziarah yang mempunyai hajat dan akan melepaskan nazarnya, baik berupa kambing maupun ayam. Bahkan ada juga peziarah yang nazarnya untuk melepaskan berupa kerbau atau sapi.

Demikian pula pihak yayasan Syekh Yusuf Tuanta Salamaka dan penarikan retribusi setiap pengunjung dikenakan biaya perorang yang dikelolah oleh Dinas Pariwisata Kabupaten Gowa. Sedang pihak yayasan hanya menampung berupa passidakkah (sumbangan) dari para peziarah sesuai dengan keiklasan masing-masing. Dalam setiap harinya pihak yayasan diperkirakan dapat menerima sumbangan sampai jutaan rupiah.

Para peziarah yang datang berkunjung ke Makam Syekh Yusuf Tuanta Salamaka di kobbbanga, selain membayar retribusi dari Dinas Pariwisata Kabupaten Gowa, memberi sumbangan kepada yayasan, serta passidakka (sedekah) kepada guru maca (pembaca do'a), maka sebagai wujud kegembiraan dari ziarah kubur Tuanta Salamaka dengan memberikan atau membagi-bagikan uang kepada anak-anak paraggak doek.

Dari pengertian diatas dapat dirumuskan pengertian sosial ekonomi adalah gambaran tentang kondisi seseorang atau suatu masyarakat yang ditinjau dari segi sosial dan ekonomi. Gambaran tersebut meliputi tingkat pendidikan, tingkat pendapatan, jumlah keluarga dan sebagainya

Dalam kehidupan sosial ekonomi masyarakat terdapat proses dan pola interaksi sosial, dalam hubungannya dengan ekonomi. Hubungan tersebut dilihat 
dari saling pengaruh-mempengaruhi. Masyarakat sebagai realitas eksternalobjektif akan menuntun individu dalam melakukan kegiatan ekonomi seperti apa yang boleh diproduksi, bagaimana memproduksinya, dan dimana memproduksinya. Tuntutan tersebut biasanya berasal dari budaya, termasuk di dalamnya hukum dan agama. (Damsar 2009 : 12)

Adanya makam Tuanta Salamaka membawa dampak tersendiri bagi masyarakat sekitarnya dan peziarah, dalam hal ini terhadap kehidupan sosial ekonomi masyarakatnya. Dalam bidang sosial ekonomi dapat dilihat dari segi mata pencaharian penduduk yang disebut sebagai suatu usaha manusia yang bernilai ekonomis dilakukan oleh manusia secara berkesinambungan dengan tujuan untuk mendapatkan penghasilan yang tetap. Mata pencaharian mempunyai sifat tetap dan sewaktu-waktu sebagai usaha sampingan untuk menambah kebutuhan hidup sehari-hari. Dengan mempunyai penghasilan, maka seseorang dapat mempertahankan kelangsungan hidupnya.

\section{PENUTUP}

Syekh Yusuf yang lebih populer dengan sebutan namaTuanta Salamaka, terlahir dari seorang perempuan bernama SittiAminah, puteri Gallaarrang Moncongloe, pada tahun 1626. Syekh Yusuf selain dikenal sebagai seorang ulama, sufi, dan cendikiawan yang arif, juga adalah seorang pejuang sejati. Sebagai seorang pahlawan, maka ia merupakan sosok pemimpin berani dan cerdas serta ahli strategi dalam perang. Ia paling sangat menentang dengan kehadiran Kolonial Belanda di Bumi Indonesia.

Motivasi spiritual para peziarah terbagi kedalam tiga kategori. Pertama, Motivasi aqidah adalah keyakinan hidup. Kedua, motivasi ibadah merupakan motivasi yang pernah dilakukan oleh orang yang memiliki agama, seperti shalat,doa, dan puasa. Ketiga, motivasi muamalah adalah tata aturan ilahi yang mengatur hubungan manusia dengan sesama manusia dan manusia dengan benda atau materi alam. Dilihat dari segi sosial ekonomi, membawa dampak positif bagi masyarakat dan peziarah yaitu selain pembangunan sarana dan prasarana yang baik dan yang pasti menjamin kesejahteraan masyarakat meningkat yang 
menyebabkan perekonomian menjadi hidup dan keuntungan bertambah sehingga mempercepat gerak ekonomi masyarakat setempat dengan berjualan segala macam jenis ketika sedang ramai peziarah.

Dampak peziarahan di Makam Tuanta Salamaka yang di rasakan oleh peziarah. Pertama hidup jadi tenang, tentram, keluarga harmonis, rejeki lancar, memiliki kepercayaan diri dalam berinteraksi dengan orang banyak, terbuka mata hati serta pikiran mereka, kini mereka dapat melakukan kebiasaan baik. Kedua adalah dampak ekonomi yang secara langsung dapat di rasakan para peziarah, misalnya dengan usaha berdagang di sekitar Makam. 


\section{DAFTAR PUSTAKA}

Damsar, 2009.Pengantar Sosiologi Ekonomi Edisi Revisi, Jakarta: Kencana Prenada Media Group

Geertz, Clifford, 1983. Abangan, Santri, dan Priyayi dalam Masyarakat Jawa, terj. Aswad Mahasin, Jakarta: Pustaka Jaya

Hamid, Abu, 1994. Syekh Yusuf, Seorang Ulama, Sufi dan Pejuang. Kata Pengantar Taufik Abdullah, Jakarta: Yayasan Obor Indonesia

Kila, Syahrir, 1998/1999; Tingkat Kesadaran Sejarah Lokal Siswa SLTA DiKabupaten Gowa, Ujungpandang: Balai Kajian Sejarah dan Nilai Tradisional Ujungpandang

Montana, Suwedi, 1996/1997. Makam-makam Islam Kuno Di Soppeng SulawesiSelatan, Proyek Pengembangan Media Kebudayaan Direktorat Jenderal Kebudayaan. Jakarta: Departemen Pendidikan dan Kebudayaan

Mukhlis - Robinson, Katrhryn (Editor), 1985.Agama dan Realitas Sosial, Diterbitkan Untuk Yayasan Ilmu-Ilmu Sosial, Ujungpandang: Lembaga Penerbitan Unhas (Lephas)

Rasyid, Darwas, T.Th. 1994; Biografi Syekh Yusuf. Ujungpandang: Balai Kajian Sejarah dan Nilai Tradisional Ujungpandang

Romondt,HR Van, 1985 ;Makam-Makam Islam Di Sulawesi Selatan, Amerta Berkala Arkeologi, Cet.II, Jakarta: Pusat Penelitian Arkeologi Nasional

Santoso, Halina Budi, 1980 ;Catatan Tentang Perbandingan Nisan Kubur DiBeberapa Daerah Indonesia: Pertemuan Ilmiah Arkeologi I - 1977, p.486-497

Shri Ahimsa Putra, Heddy, 2001 ;Strukturalisme Levi Strauss Mitos dan KaryaSastra, Diterbitkan Atas Kerjasama Yayasan Adikarya Ikapi Dan The Ford Foundation, Yogyakarta: Penerbit Galan Press,

Simuh, 2003. Islam dan Pergumulan Budaya Jawa, Yogyakarta: Teraju

Sudewo, Eri, 1990 ;Pemujaan Kubur: Distorsi Atau Retradisional ?, Procedings Analisis Hasil Penelitian Arkeologi Indonesia

Soekanto, 1986. Soerjono.Sosiologi Suatu Pengantar. Jakarta: PT Raja Grafindo Persada. 
Soekatno,Tw. (Ed), 1982/1983 ; Ragam Hias Beberapa Makam Islam Di SulawesiSelatan, Proyek Pemugaran dan Pemeliharaan Peninggalan Sejarah dan Purbakala Jakarta, Jakarta.

Suhadi Machi, 1994/1995 ;Makam - makam Walisanga Di Jawa, Departemen Pendidikan dan Kebudayaan, Jakarta.

Sulthan, Sahib, 2005 ;Syekh Yusuf Tuanta Salamaka Ulama Sufi, Pejuang Abadke-17, Pahlawan Nasional, Yapma.

Tujimah, 1997 ;Syekh Yusuf Makassar Riwayat Hidup dan Ajarannya, UI Press.

Wahosumidjo, 1992. Kepemimpinan dan Motivasi, Jakarta: Ghalia Indonesia. 